\title{
Half-Earth or Whole-Earth? Green or transformative recovery? Where are the voices from the Global South?
}

\author{
A SHISH KOTHARI
}

A debate is swirling around various bold proposals to protect biodiversity. One of these proposals arose in part from E.O. Wilson's (2016) book Half-Earth: Our Planet's Fight for Life. The essence of the idea is summarized by the Half-Earth Project (2021), which '... is working to conserve half the land and sea to safeguard the bulk of biodiversity, including ourselves'. Critics have argued the idea is fraught with implications for human rights, likely to be ineffective and that-contrary to the proposal-transformations in economic activity across the Earth are needed to bring us within ecological limits (Büscher et al., 2017).

In parallel to this and related ideas (e.g. CBD, 2020), new approaches to development in a post COVID-19 world are being proposed, some of which - such as nature-based solutions-are attracting mainstream attention. The basic tenets, of acting in accordance with the principles and flows of nature, with sustainable management and use of nature for tackling socio-environmental challenges, are unexceptionable. But this approach too ignores the power and rights dimensions of such solutions, and lends itself to another kind of greenwash, in which corporations and governments continue their destructive activities while paying or pressurizing others to offset them (Global Forest Coalition, 2020a).

But what I find of greatest concern in all these proposals and approaches is their origin in the Global North. Most of the proponents, and even many of their critics, are based in institutions in northern or western countries, or in the rich and powerful sections of the south. Noticeably missing or weakly represented are voices from the Global South (e.g. Agrawal, 2020), including Indigenous people or other local communities who live amidst or use the areas containing most biodiversity.

If conservationists of the Global North are serious about saving the Earth, and I would like to believe they are, then they need to listen carefully to people such as Nemonte Nenquimo of the Waorani Indigenous people in the Amazon ('This is my message to the western world-your civilization is killing life on Earth'; Nenquimo, 2020), and to those communities who have told the advocates of nature-based solutions that 'our nature is not your solution' (Global Forest Coalition, 202ob). Global networks

Ashish Kothari Kalpavriksh Environment Impact Group, Apartment 5, Shree Dutta Krupa, 908 Deccan Gymkhana, Pune 411 004, India

E-mail ashishkothari@riseup.net comprising Indigenous peoples and local community organizations and civil society groups, such as the Indigenous Peoples' \& Community Conserved Territories \& Areas Consortium (ICCA, 2021), and the Global Forest Coalition, have shown how community-led conservation approaches, especially if there is a supportive policy context such as recognition of tenure and the right of self-determination, can work. Evidence supports this (Bennett \& Ramos, 2019; Fernández-Llamazares et al., 2020). The movement to recognize governance of Indigenous peoples and local communities over their territories of life has asserted that coexistence between humans and nature is not only possible, but best achieved under such governance or under equitable co-governance with formal conservation agencies. This movement seeks recognition and support from governments and international institutions, but not of the top-down or patronizing kind, and it seeks the cessation of exploitative, extractive economic activities not only in their territories, but everywhere.

The Half-Earth protagonists are close to Indigenous visions in their entreaties for an ethical relationship with the Earth. But the commonality is somewhat superficial. Most Half-Earth protagonists live in conditions radically altered by industrialization: they cannot possibly imagine living one's whole life as an artisanal hunter, gatherer, fisher, farmer or forestdweller whose livelihood, culture, entertainment, language, food, relationships and emotions are conditioned by everyday interactions with the natural world. As Nenquimo says:

It took us thousands of years to get to know the Amazon rainforest. . . This forest has taught us how to walk lightly, and because we have listened, learned and defended her, she has given us everything: water, clean air, nourishment, shelter, medicines, happiness, meaning. And you are taking all this away, not just from us, but from everyone on the planet, and from future generations.

Even those of us in the south living in cities (I include myself) are unable to adequately fathom such a life. The non-duality such communities thrive on is lost on those of us who think in terms of humans and nature, rather than in terms of humans and the rest of nature. This is not to say that people in industrialized societies-whether in the North or South-cannot transcend their constraints and return to a life within nature, but if the Part-Earth protagonists were of this ilk it is doubtful they would propose dividing the Earth into separate parts, one for nature, the other for humans. This duality is the biggest flaw in these approaches.

Rather, following the calls of Indigenous peoples and local communities, we have to imagine and struggle for 
an approach that strives for co-existence amongst all species, including humans. This means taking Nenquimo's message to its logical conclusion: a radical re-imagination of civilization itself, a systemic transformation towards a more just, sustainable, equitable world that does not base itself on the futile promise of continuous economic growth. Here, too, there are diverse ways of achieving and sustaining well-being (Kothari et al., 2019; GARN, 2021).

The need for fundamental change has not escaped the attention of northern scholars. Sandbrook et al. (2020) examined the likely political and economic responses to the COVID-19 pandemic, and stressed the need for transformative economic reconstruction, noting that green recovery approaches will simply not be enough. But even they limit their horizon to approaches to degrowth emanating from the Global North, and do not mention the radical approaches emerging or resurfacing in the Global South. Some of us have recently laid out key principles for a new, post-growth approach to conservation (Fletcher et al., 2020): conviviality, diversity, decommodification, valuing the sacred in nature, decolonization, social justice, direct democracy, redistribution, subsidiarity, global interconnectedness, linking conservation and resistance, and redefining power. These come from listening closely, being involved with grassroots movements, but it is not an attempt to speak on behalf of these movements. They must be enabled to speak for themselves in debates on the future of conservation, or indeed the future of Earth.

The COVID-19 slap in humanity's face should make us realize it is not enough to set ambitious biodiversity targets, such as those set in 2001 and 2010, both largely missed. Without fundamental change encompassing Whole-Earth, we are looking at a prospect of No-Earth. We are already being engulfed in a wave of post COVID-19 greenwash in the name of green recovery, and although so-called green new deals are head and shoulders above conventional development paradigms, they do not go far enough in challenging political and economic structures of unsustainability and inequality (Kolinjivadi \& Kothari, 2020). A robust recovery must focus on revolutions of multiple hues, a rainbow approach that integrates conservation, livelihood security, democratic practice, and solidarity-based economies across entire landscapes and seascapes.

Before our further interference in nature results in the next pandemic, conservationists, from Indigenous peoples and local communities to scientists and civil society groups, need to combine their expertise in an atmosphere of mutual respect and equitable collaboration. To succeed we need the Global North to shed its remnant colonialism and to acknowledge the central role of the Global South, both in the specific arena of conservation and in the wider paradigms of planetary well-being.

\section{References}

Agrawal, A., Bawa, K., Brockington, D., Brosius, P., D'Souza, R., DeFries, R. et al. (2020) Open Letter to Waldron et al. openlettertowaldronetal.wordpress.com [accessed 19 January 2021].

Bennett, N. \& Ramos, A. (2019) Recognising and Supporting Indigenous Leadership in Conservation. iucn.org/news/commissionenvironmental-economic-and-social-policy/201908/recognisingand-supporting-indigenous-leadership-conservation [accessed 19 January 2021].

Büscher, B., Fletcher, R., Brockington, D., Sandbrook, C., Adams, W.M., Campbell, L. et al. (2017) Half-Earth or Whole Earth? Radical ideas for conservation, and their implications. Oryx, 51, 407-410.

CBD (2020) Zero Draft of the Post-2020 Global Biodiversity Framework. cbd.int/article/2020-01-10-19-02-3 [accessed 26 January 2021].

Fernández-Llamazares, Á., Terraube, J., Gavin, M.C., Pyhälä, A., Siani, S.M.O., CabeZa, M. \& Brondizio, E.S. (2020) Reframing the wilderness concept can bolster collaborative conservation. Trends in Ecology \& Evolution, 35, 750-753.

Fletcher, R., Masarella, K., Kothari, A., Das, P., Dutta, A. \& Búscher, B. (2020) A new future for conservation. Progressive International, 10 August 2020. progressive.international/blueprint/ e6eoga9o-dco9-41od-af87-5d3339ad4ed3-fletcher-et-al-a-newfuture-for-conservation/en [accessed 19 January 2021].

GaRN (Global Alliance for the Rights of Nature) (2021) therightsofnature.org [accessed 19 January 2021].

Global Forest Coalition (2020a) Action Alert: Join Us to Oppose Nature-Based Solutions Greenwash on International Day for Biological Diversity. globalforestcoalition.org/our-nature-is-notyour-solution [accessed 19 January 2021].

Global Forest Coalition (2020b) Forest Cover 61: \#OurNatureIsNotYourSolution, International Day for Biological Diversity. globalforestcoalition.org/forest-cover-61 [accessed 19 January 2021].

Half-Earth Project (2021) half-earthproject.org [accessed 19 January 2021].

ICCA (Indigenous Peoples' \& Community Conserved Territories \& Areas Consortium) (2021) iccaconsortium.org [accessed 26 January 2021].

Kolinjivadi, V. \& Kothari, A. (2020) No harm here is still harm there: the Green New Deal and the Global South (I). Jamhoor, 20 May 2020. jamhoor.org/read/2020/5/20/no-harm-here-is-stillharm-there-looking-at-the-green-new-deal-from-the-global-south [accessed 22 January 2021].

Kothari, A., Salleh, A., Escobar, A., Demaria, F. \& Acosta, A. (eds) (2019) Pluriverse: A Post-Development Dictionary. Tulika Books and Authorsupfront, New Delhi, India.

Nenquimo, N. (2020) This is my message to the western worldyour civilisation is killing life on Earth. The Guardian, 12 October 2020. theguardian.com/commentisfree/2020/oct/12/westernworldyour-civilisation-killing-life-on-earth-indigenous-amazonplanet [accessed 19 January 2021].

Sandirook, C., Gómez-Baggethun, E. \& Adams, W.M. (2020) Biodiversity conservation in a post-COVID-19 economy. Oryx, published online 3 December 2020.

Wilson, E.O. (2016) Half-Earth: Our Planet's Fight for Life. Liveright, New York, USA. 